\title{
ORGANIZATIONAL SLACK EFFECTS ON INNOVATION: THE MODERATING ROLES OF CEO TENURE AND COMPENSATION
}

\author{
Fariss-Terry Mousa ${ }^{1}$, Jaideep Chowdhury ${ }^{2}$ \\ ${ }^{1}$ Department of Management, College of Business, James Madison University, MSC 0205, \\ 421 Bluestone Dr. ZSH525,VA 22807 Harrisonburg, USA \\ ${ }^{2}$ Department of Finance and Business Law, College of Business, James Madison University, \\ MSC 0204, 421 Bluestone Dr., ZSH322, VA 22807 Harrisonburg, USA \\ E-mails: ${ }^{1}$ mousafx@jmu.edu (corresponding author); ${ }^{2}$ chowdhjx@jmu.edu
}

Received 01 February 2013; accepted 27 August 2013

\begin{abstract}
This study draws on upper echelons theory, the resource based view, and Penrose's theory of firm growth to show that slack resources, specifically financial and human slack, are essential to the research and development (R\&D) strategies of organizations. We also suggest that both Chief Executive Officer (CEO) tenure and CEO compensation positively moderate the slack-innovation relationship.

The empirical design compromised of panel regression analysis. We tested our hypotheses using all US publicly traded firms between 1993 and 2011.

The research results show that firms with excess financial resources are more likely to have higher R\&D investments, and to completely understand this relationship we must study CEO tenure and compensation.

This study sheds light on central antecedents of firm innovation, it further extends our understanding by investigating the impact of CEO tenure and compensation on the slackinnovation relationship, and it applies a longitudinal design which answers previous calls to investigate this topic in more depth by offering enhanced stability to the results while allowing for different economic scenarios.
\end{abstract}

Keywords: financial slack, human slack, CEO tenure, CEO compensation, firm innovation intensity, R\&D investments.

Reference to this paper should be made as follows: Mousa, F.-T.; Chowdhury, J. 2014. Organizational slack effects on innovation: the moderating roles of CEO tenure and compensation, Journal of Business Economics and Management 15(2): 369-383.

JEL Classification: J33, O31, O32.

\section{Introduction}

This study enhances our understanding of the impact of organizational resources on firm innovation. The importance of resources in firm innovation cannot be emphasized enough. Many scholars, building on Penrose's (1959) work, have argued that resources, and the capability to effectively mobilize them, are essential to organizational innova- 
tion (Levinthal, March 1981). A better understanding of the nature of the resources needed to support innovation is therefore essential. This is particularly true given that innovation is the driving force behind economic development (Schumpeter 1934) and essential to any firm dreaming of a place in the competitive world of the future (Van de Ven 1986). This study, therefore, aims to inform the literature on exactly how slack resources influence the organizational commitment to innovation.

The impact of organizational slack on firm outcomes has been perceived as both a positive and a negative. On one hand, slack has been perceived as essential to various organizational outcomes. Cyert and March (1963) provided the seminal answer to this puzzle when they argued that for organizations to survive, and for their political coalitions and subgroups to meet competing goals, slack must exist. Later researchers built on this work, suggesting that slack prevents unhealthy conflict (Bourgeois, Singh 1983) and creates buffers that reduce information-processing and coordination costs across subunits (Galbraith 1973). More recently, scholars have argued that slack supports innovation (Singh 1986), firm expansion (Bamford et al. 2000), young firm IPO valuation (Mousa, Reed 2013), and growth (Bradley et al. 2011). Some researchers, however, have countered that slack is an indication of waste. For instance, excess resources may decrease efficiency, resulting in performance below the full potential of the available resources (Williamson 1963). These scholars argue that slack may interrupt the entrepreneurial process (Mosakowski 2002) and negatively impact entrepreneurial management (Bradley et al. 2011).

In this study, we specifically focus on two types of organizational slack: financial and human slack. Building on the literature in the two broad categories of financial and human slack (e.g., Cooper et al. 1994; Mishina et al. 2004), we argue that slack is crucial to facilitating and sustaining innovation in organizations and suggest that such resources not only impact growth (Mishina et al. 2004), but also directly impact firm innovation. We further argue that CEO tenure and compensation, combined with slack resources, impact $R \& D$ spending. The research and development $(R \& D)$ process generally requires ample time and resources, and entails some risk. Both financial and human resources are particularly necessary throughout the R\&D process. For instance, not only do financial resources aid the R\&D process from an operational point of view, they are essential to the acquisition of equipment, technology, new research labs, and the hiring of scientists.

\section{Theoretical foundations and hypothesis development}

\subsection{Financial slack, human slack, and R\&D investments}

Financial slack refers to the level of assets available to an organization (e.g., cash on hand) (Kraatz, Zajac 2001) that can be easily deployed to various uses (Mishina et al. 2004). Financial slack is the least absorbed form of slack, especially given that it is completely divisible for the allocation of multiple activities (Greve 2003).

From a resource based view (RBV), financial assets are valuable, but not rare, because they are generic (Latham, Braun 2008). Even though managers have considerable discretion in resource allocation, they have to be very careful to make good decisions and 
avoid misusing finite resources. Firms with increased organizational resources are more likely to engage in essential activities like R\&D (Cyert, March 1963). For instance, R\&D investments generally push firms to explore the unknown that may or may not result in payoff. When payoff comes, it is often slow, thus increasing risk. For instance, to look at an extreme case, developing an innovative new drug takes on average 12 years and 800 million dollars (DiMasi et al. 2003). Only firms with considerable financial slack and commitment to innovation will take on uncertain multiyear projects with opportunity costs and capital investment requirements such as these. Financial slack, therefore, offers a safety net that enables these firms to pursue new ideas and projects with longer investment horizons and less certain outcomes (Kim et al. 2008). Not only does financial slack insulate against cash flow volatility, it also maintains R\&D investment through good times and bad (O'Brien 2003).

Next, we focus on the impact of human slack on innovation intensity. Both financial and human slack differ greatly in their degree of stickiness, which is a function of resource divisibility and fungibility (Penrose 1959). Penrose (1959) described 'stickiness' as the extent to which slack resources can be quickly and opportunistically utilized to fuel expansion. More specifically, divisibility relates to how easily the amount of a given resource can be adjusted to the demands of a situation, while fungibility pertains to whether a given resource can be applied to multiple ends interchangeably. Therefore, 'stickier' resources are harder to manage than more liquid resources because they cannot be allocated in unit amounts that match the demands of the situation (e.g., a machine could have a greater minimum capacity than a firm's current needs) (Mishina et al. 2004). Another important point is that once such resources are assigned to a specific task, they may or may not be adaptable to new or changed tasks (Mishina et al. 2004). For instance, if market demands shift, a machinist will find it hard to suddenly become a plumber.

As mentioned earlier, human slack is context driven and is more tied to the nature of organizational routines than is the value of financial resources. This is simply because human knowledge and skills tend to be embedded in specific tasks and organizational contexts (Knorr-Cetina 1999). Task expertise is also limited to narrow knowledge domains (Chi et al. 1988), and thus, this expertise is more difficult to transfer across situations (Szulanski 2003) than more generic financial resources. Thus, slack in these two resources is differently useful to firms pursuing distinct innovation investment strategies. We therefore argue that for these 'stickier' human resources, the influence of slack on the commitment to R\&D is dependent, at least in part, on both the path-dependent and firm specific nature (Arthur 1989; David 1985) of human resources. This could be extremely beneficial to a firm if, for example, competitors are unable to obtain similar resource configurations and may thus have difficulty copying the firm's strategies (Barney 1991). This pool of human resources might be useful if a firm needs to intensify its R\&D efforts given their ability to draw on and reposition resources to support current initiatives. Thus, firms with more human resources should be better able to apply needed resources to a specific project, keep these resources involved and focused on an $R \& D$ initiative to fruition. The commitment to $R \& D$ may be the force behind some 
of history's greatest firm inventions and successes. Take for instance Google's decision to allow engineers to spend $10 \%$ of their time on projects of their choosing. Managers at Google believe that some of the best innovations come from unstructured work time (e.g., Gmail). It is difficult to see how structured environments can constantly perform and innovate without slack. The availability of excess resources seems key, especially when it comes to innovation. Thus, our arguments here boil down to the idea that organizational slack (i.e., both financial and human) permits firms to divert their attention from "fire fighting" and focus on expansive thinking and risky, innovative projects with potentially high payoffs (Nohria, Gulati 1996). Taking all of this together, we thus hypothesize:

H1a: Financial slack will positively relate to firm innovation intensity.

H1b: Human slack will positively relate to firm innovation intensity.

\subsection{CEO tenure and the slack-innovation relationship}

Here we focus on the impact of CEO tenure on the slack-innovation relationship because tenure has been proposed as an important influence on strategic investment (Hambrick, Mason 1984). The key question here is, how does a CEO's time in office affect the slack-innovation relationship? Wu et al. (2005) argued that CEO behavior in assigning, organizing, and stirring firm resources can significantly affect a firm's inventive capability. We extend this argument by suggesting that CEO behaviors contribute substantially to an organization's commitment to innovation through investment in R\&D. CEOs with more tenure are probably better performers - because they have lasted so long (Allgood, Farrell 2000). Tenure could be positively correlated, therefore, with managerial talent and quality (Berger et al. 1997). Such skill, quality, and experience make them generally better and more sophisticated managers of excess financial and human resources. It takes time for a CEO to fully understand the types of resources possessed by the firm and to understand how to bundle such resources to achieve and sustain competitive advantage. Thus, for a CEO to accurately and fully fund important initiatives, he or she must look beyond the financial statements that are traditionally used by top managers. The same applies to human resources and their specialized knowledge which is essential in creating competitive advantage (Barney 1991). Competitive markets promote concentrated efforts to retain and protect these skilled and specialized employees, and therefore, by reducing the ease with which such employees can be acquired, these competitive efforts increase the rarity of human slack resources (Voss et al. 2008).

Further, continuous investment in R\&D requires dedication to the firm's long term objectives and a deep understanding of how innovation works and how long it can take. Short term focus (e.g. worrying about quarterly results) can be characteristic of newly hired CEOs, and may limit innovation. Newly hired CEOs may feel that excess capital is better spent adding value to the bottom line by growing the sales and marketing departments' budgets, expanding to new markets, or acquiring other firms. A new CEO must ensure early success in a number of categories (building internal and external networks, solidifying and expanding their power, developing knowledge specific to their firms and industries, and showing preliminary success to shareholders) before they can 
worry about innovation (Wu et al. 2005). Given the risky nature of R\&D, it also seems reasonable to suggest that newer CEOs will be hesitant to make large cash investments in innovative projects where a payoff may never materialize. On the other hand, some research (Berger et al. 1997) has argued that CEOs with longer tenures and better compensation are more entrenched and thus less likely to invest in risky projects. We side with and extend the work of Guay (1999), who argued that CEOs with higher total cash compensation are better diversified - they have more capital that is invested outside their firm - and are therefore less risk averse. Therefore, CEOs with longer tenures seem to not only have a better understanding of the firm's resources and capabilities, but also the wisdom to continuously invest in $R \& D$ projects that might materialize down the road. Thus, we hypothesize:

H2a: CEO tenure positively moderates the financial slack-innovation intensity relationship.

H2b: CEO tenure positively moderates the human slack-innovation intensity relationship.

\subsection{CEO compensation and the slack-innovation relationship}

Generally, organizations can take both short- and long-term approaches to innovation (Leonard-Barton 1995), for instance, through a combination of incremental, cumulative, and radical innovations that are generally intertwined (Saviotti, Mani 1998). With suitable compensation for both short- and long-term innovations, a CEO should be motivated to manage the flow of products through a firm's innovation pipeline into the market (Balkin et al. 2000). It is important to reiterate that investments in innovation are inherently risky (Baysinger et al. 1991). Focusing on innovation implies greater variability of outcomes and a greater probability of failure (Balkin et al. 2000). Thus, CEOs who are willing to use these excess resources to invest in R\&D must and should receive higher total compensation in return for bearing greater risk (Finkelstein, Hambrick 1996). This is especially true given that these CEOs risk a negative reputation in the market if such pricey investments fail to provide the desired results (Balkin et al. 2000). It is difficult for outsiders to distinguish unfortunate circumstances from poor decisions (Wiseman, Gomez-Mejia 1998). For instance, research has revealed that negative information carries more weight than positive information (Edder, Ferris 1989).

We build on these arguments by suggesting that proper compensation will motivate CEOs to channel firm resources (financial and human) towards innovative short- and long-term projects in hopes of gaining and sustaining competitive advantage. Executive compensation should increase accordingly (Balkin et al. 2000) both because the board will likely recognize the multitude of decisions required in such situations, and because the board understands the importance of attracting and retaining superior managers over 'bad' managers (Hambrick, Finkelstein 1987). Chief executives with higher total cash compensation have more diversified investments and therefore are more likely to invest in riskier projects (Guay 1999). In addition, firms themselves "appear to provide managers with incentives to invest in risky projects when the potential loss from forgoing valuable risk-increasing projects is greatest" (Guay 1999: 45). Finally, wealthier 
individuals generally invest in riskier and longer-term projects simply because they can afford to risk more (Frank 2007). Building on these arguments, we suggest that CEOs with higher total compensation will be better motivated to manage and bundle firm resources (financial and human) to ensure continuity and intensity in the commitment to innovation. Therefore we propose:

H3a: Total CEO compensation positively moderates the financial slack-innovation intensity relationship.

H3b: Total CEO compensation positively moderates the human slack-innovation intensity relationship.

\section{Methods}

\subsection{Sample description}

Our universe of firms consists of all publicly traded US firms on the NYSE, AMEX, and Nasdaq in the ExecuComp database from 1993 to 2011. We excluded financial services and utility firms (SIC codes 6000 - 6999 and 4900 - 4999). For all accounting variables we relied on Compustat database while we obtained stock returns data from CRSP. We excluded firms with incomplete Compustat asset, sales, or R\&D data. We specifically obtained CEO compensation and tenure data from Execucomp database. For one of the control variables, G-index, we used Riskmetrics dataset ${ }^{1}$. We merged CRSP with Compustat using the variable cusip. We matched firms from this merged CRSP Compustat database with firms from Execucomp database using the variable gvkey. Then we merged the combined dataset with the Riskmetrics dataset using the variable cnum $^{2}$. Our final sample consists of 7,729 firm years.

\subsection{Measures}

Firm innovation intensity, the dependent variable was measured by the ratio of R\&D expenditures to total assets ${ }^{3}$.

Two variables, financial and human slack, were used to measure organizational slack. Financial slack is measured as cash + short term investments +0.7 (total receivables) + 0.5 (total inventory) - longterm debt due in one year divided by PP\&E (Cleary 1999). Positive financial slack implies that cash and other current assets are being maintained at a higher level than necessary. Negative financial slack, on the other hand, implies that a firm is stretching its resources further than expected (Mishina et al. 2004). Human slack, was calculated as (firm employees/firm sales - industry employees/industry sales) (Mishina et al. 2004). Positive human slack indicates that the firm has more human resources at its disposal than its industry peers which can be allocated toward innovation.

\footnotetext{
${ }^{1}$ G-Index is a composite index of corporate governance developed by Gompers et al. (2003) and used in several leading papers in Finance (e.g., Cremers, Nair 2005).

${ }^{2}$ All four databases - CRSP, Compustat, Execuomp, and Riskmetrics - could be accessed through Wharton Research Data Services (WRDS) from the University of Pennsylvania.

${ }^{3}$ Variables used in our analysis will be denoted in italics hereafter in the main text of the paper.
} 
Negative human slack implies that managers are constrained in terms of human capital and cannot afford to allocate human capital towards innovation. Industry is defined by the three digit SIC code, also found in Compustat.

Two moderators were used. The first, tenure, was measured as the number of years an individual had been the CEO of a given firm (current year - year CEO took office) (Hill, Phan 1991).The second, total compensation, measured as the sum of salary, bonus, other annual compensation, restricted stock grants, long term payouts, all other compensations, and the value of option grants (Chhaochharia, Grinstein 2009).

\subsection{Control variables}

We controlled for firm age (current year - year the firm went public) and firm size (total firm assets, in millions of dollars). Larger and older firms should have more resources to allocate to innovation (Cohen, Klepper 1996; Hansen 1992). We controlled for leverage (the sum of long term debt and short term debt divided by total assets) (Singh, Faircloth 2005), profitability (the sum of income, before extraordinary income, and depreciation scaled by total assets) (Audretsch 1995), Tobin's $q$ - growth opportunities (the ratio of the market value of assets to the book value of assets) (Szewczyk et al. 1996), stock returns volatility (volatility of the past year's daily stock returns) (Mazzucato, Tancioni 2012; Core, Guay 1999), G-Index - a corporate governance variable (Hermalin, Weisbach 1998) and managerial ownership (percentage of ownership) (Francis, Smith 1995).

\section{Methods of analysis}

We employed panel regression and included firm fixed effects to incorporate any omitted and unobserved firm specific factors, year fixed effects to control for macroeconomic conditions which may affect $R \& D$ and differ across sample years, and industry fixed effects to account for any omitted industry specific factors which may be driving the results. We used Newey West standard errors while measuring the t statistics to control for the possibility of heteroskedasticity in the error terms.

\section{Results}

In panel A of Table 1, we report the descriptive statistics of our dependent and independent variables. The correlation coefficients between all of our variables are shown in panel B Table 1. None of the correlation coefficients are large enough to indicate multicollinearity ${ }^{4}$.

\footnotetext{
${ }^{4}$ We estimate the variance inflation factors (VIFs) for all of our regression analyses and find that none of them are greater than 3, indicating that our models (as reported in Table 2) do not have the problem of multicollinearity. We do not report the VIFs of our regression analysis; they are available upon request.
} 
Table 1. Descriptive statistics and correlation matrix

\begin{tabular}{|c|c|c|c|c|c|c|c|}
\hline \multicolumn{2}{|c|}{ Panel A } & Mean & Median & StdDev & $\begin{array}{c}\text { Lower } \\
\text { Quartile }\end{array}$ & $\begin{array}{c}\text { Upper } \\
\text { Quartile }\end{array}$ & Skewness \\
\hline \multicolumn{8}{|c|}{ Dependent variables } \\
\hline \multicolumn{2}{|l|}{$\mathrm{r} \& \mathrm{~d} /$ asset } & 0.055 & 0.029 & 0.075 & 0.007 & 0.078 & 3.782 \\
\hline \multicolumn{8}{|l|}{ Slack } \\
\hline \multicolumn{2}{|c|}{ financial slack } & 2.761 & 1.128 & 8.220 & 0.478 & 2.495 & 17.695 \\
\hline \multicolumn{2}{|c|}{ human slack } & 0.005 & 0.004 & 0.008 & 0.003 & 0.006 & 36.525 \\
\hline \multicolumn{8}{|c|}{ CEO level variables } \\
\hline \multicolumn{2}{|l|}{ tenure } & 6.301 & 4.000 & 6.834 & 2.000 & 9.000 & 1.829 \\
\hline \multicolumn{2}{|c|}{$\begin{array}{l}\text { total compensation } \\
\text { (in } 000 \mathrm{~s} \text { ) }\end{array}$} & 5615.073 & 3321.077 & 10507.427 & 1706.042 & 6568.689 & 25.652 \\
\hline \multicolumn{2}{|c|}{$\begin{array}{l}\text { percentage of } \\
\text { ownership }\end{array}$} & 1.426 & 0.250 & 4.072 & 0.083 & 0.823 & 7.674 \\
\hline \multicolumn{8}{|c|}{ Control variables } \\
\hline \multicolumn{2}{|l|}{ asset } & 7053.990 & 1750.428 & 19178.753 & 661.894 & 5384.810 & 8.182 \\
\hline \multicolumn{2}{|c|}{ profitability } & 0.089 & 0.100 & 0.118 & 0.062 & 0.140 & -5.673 \\
\hline \multicolumn{2}{|l|}{ leverage } & 0.224 & 0.216 & 0.166 & 0.098 & 0.325 & 0.951 \\
\hline \multicolumn{2}{|l|}{ tobin $\mathrm{q}$} & 1.654 & 1.264 & 1.406 & 0.892 & 1.922 & 6.192 \\
\hline \multicolumn{2}{|c|}{$\log$ (volatility) } & 0.089 & 0.062 & 0.133 & 0.037 & 0.109 & 36.917 \\
\hline \multicolumn{2}{|l|}{ firm age } & 29.522 & 28.000 & 16.375 & 14.000 & 44.000 & 0.209 \\
\hline \multicolumn{2}{|l|}{ gindex } & 8.934 & 9.000 & 2.834 & 7.000 & 11.000 & -0.004 \\
\hline \multicolumn{2}{|c|}{$\begin{array}{lll}\text { Panel B } & {[1]} & {[2]} \\
\end{array}$} & {$[3] \quad[4]$} & {$[5]$} & {$[7]$} & [9] & {$[10] \quad[11]$} & [12] [13] \\
\hline \multicolumn{8}{|c|}{$\begin{array}{ll}\mathrm{r} \& \mathrm{~d} / & 1.000 \\
\text { Asset }\end{array}$} \\
\hline \multicolumn{8}{|c|}{$\begin{array}{lll}\text { profitabil- } & -0.211 \quad 1.000 \\
\text { ity } & & \end{array}$} \\
\hline leverage & $-0.152-0.173$ & 31.000 & & & & & \\
\hline tobinq & $0.380 \quad 0.198$ & -0.2101 .000 & & & & & \\
\hline volatility & $0.169-0.164$ & $4-0.073 \quad 0.047$ & $7 \quad 1.000$ & & & & \\
\hline asset & -0.0800 .052 & $0.048-0.046$ & $6-0.106$ & 1.000 & & & \\
\hline firm age & -0.2280 .073 & $0.128-0.159$ & $9-0.204$ & $0.259 \quad 1.000$ & & & \\
\hline $\begin{array}{l}\text { financial } \\
\text { slack }\end{array}$ & $0.318-0.121$ & $1-0.0410 .041$ & $10.109-$ & $0.052-0.093 \quad 1$ & 1.000 & & \\
\hline $\begin{array}{l}\text { human } \\
\text { slack }\end{array}$ & $0.039-0.102$ & $2-0.0120 .042$ & 20.010 & $0.079-0.087-$ & $0.067 \quad 1.000$ & & \\
\hline gindex & -0.1940 .037 & $0.146-0.125$ & $5-0.138$ & 0.0250 .368 & $0.078-0.025$ & 1.000 & \\
\hline
\end{tabular}


End of Table 1

\begin{tabular}{|c|c|c|c|c|c|c|c|c|c|c|c|c|c|}
\hline Panel B & {$[1]$} & [2] & [3] & [4] & [5] & [6] & [7] & [8] & [9] & [10] & [11] & [12] & [13] \\
\hline $\begin{array}{l}\text { percentage } \\
\text { of owner- } \\
\text { ship }\end{array}$ & -0.036 & 0.021 & -0.03 & -0.00 & 0.045 & -0.09 & -0.19 & 0.050 & 0.049 & -0.14 & 1.000 & & \\
\hline
\end{tabular}

\begin{tabular}{lllllllllllll}
\hline total com- & 0.024 & 0.053 & -0.003 & 0.110 & -0.025 & 0.272 & 0.113 & 0.013 & -0.060 & 0.026 & -0.049 & 1.000
\end{tabular} pensation

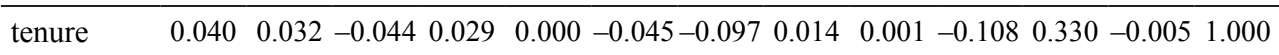

Notes: $\mathrm{p}<0.05$ for $\mathrm{r}>0.024$ and $\mathrm{p}<0.01$ for $\mathrm{r}>0.031$.

Table 2. Regression of firm innovation intensity on lag firm innovation intensity, financial slack, human slack, total compensation and tenure ${ }^{5}$

\begin{tabular}{|c|c|c|c|c|c|}
\hline & Model 1 & Model 2 & Model 3 & Model 4 & Model 5 \\
\hline Intercept & $\begin{array}{c}0.033 \\
(0.025)\end{array}$ & $\begin{array}{c}0.007 \\
(0.029)\end{array}$ & $\begin{array}{c}0.007 \\
(0.029)\end{array}$ & $\begin{array}{c}0.012 \\
(0.029)\end{array}$ & $\begin{array}{c}0.011 \\
(0.029)\end{array}$ \\
\hline lag R\&D & $\begin{array}{c}0.062 * * * \\
(0.009)\end{array}$ & $\begin{array}{c}0.052 * * * \\
(0.010)\end{array}$ & $\begin{array}{c}0.051 * * * \\
(0.010)\end{array}$ & $\begin{array}{c}0.051 * * * \\
(0.010)\end{array}$ & $\begin{array}{c}0.051 * * * \\
(0.010)\end{array}$ \\
\hline profitability & $\begin{array}{c}-0.218^{* * *} \\
(0.012)\end{array}$ & $\begin{array}{c}-0.221 * * * \\
(0.014)\end{array}$ & $\begin{array}{c}-0.216^{* * *} \\
(0.014)\end{array}$ & $\begin{array}{c}-0.216^{* * *} \\
(0.014)\end{array}$ & $\begin{array}{c}-0.213 * * * \\
(0.014)\end{array}$ \\
\hline leverage & $\begin{array}{c}-0.063 * * * \\
(0.017)\end{array}$ & $\begin{array}{c}-0.061 * * * \\
(0.019)\end{array}$ & $\begin{array}{c}-0.056^{* * *} \\
(0.019)\end{array}$ & $\begin{array}{c}-0.060 * * * \\
(0.019)\end{array}$ & $\begin{array}{c}-0.056 * * * \\
(0.018)\end{array}$ \\
\hline tobinq & $\begin{array}{c}0.291 * * * \\
(0.016)\end{array}$ & $\begin{array}{c}0.233 * * * \\
(0.019)\end{array}$ & $\begin{array}{c}0.235^{* * *} * \\
(0.019)\end{array}$ & $\begin{array}{c}0.237 * * * \\
(0.019)\end{array}$ & $\begin{array}{c}0.238^{* * *} \\
(0.019)\end{array}$ \\
\hline lagprofitability & $\begin{array}{c}-0.139 * * * \\
(0.010)\end{array}$ & $\begin{array}{c}-0.112 * * * \\
(0.012)\end{array}$ & $\begin{array}{c}-0.112 * * * \\
(0.012)\end{array}$ & $\begin{array}{c}-0.111 * * * \\
(0.012)\end{array}$ & $\begin{array}{c}-0.111 * * * \\
(0.012)\end{array}$ \\
\hline lagleverage & $\begin{array}{c}-0.073 * * * \\
(0.016)\end{array}$ & $\begin{array}{c}-0.077 * * * \\
(0.018)\end{array}$ & $\begin{array}{c}-0.078^{* * *} \\
(0.018)\end{array}$ & $\begin{array}{c}-0.076^{* * *} \\
(0.018)\end{array}$ & $\begin{array}{c}-0.077 * * * \\
(0.018)\end{array}$ \\
\hline lagtobinq & $\begin{array}{c}0.196^{* * * *} \\
(0.016)\end{array}$ & $\begin{array}{c}0.240 * * * \\
(0.019)\end{array}$ & $\begin{array}{c}0.239 * * * \\
(0.019)\end{array}$ & $\begin{array}{c}0.237 * * * \\
(0.019)\end{array}$ & $\begin{array}{c}0.236^{* * *} \\
(0.019)\end{array}$ \\
\hline $\log$ (volatility) & $\begin{array}{c}0.137 * * * \\
(0.017)\end{array}$ & $\begin{array}{c}0.127 * * * \\
(0.019)\end{array}$ & $\begin{array}{c}0.118 * * * \\
(0.019)\end{array}$ & $\begin{array}{c}0.130 * * * \\
(0.019)\end{array}$ & $\begin{array}{c}0.122 * * * \\
(0.019)\end{array}$ \\
\hline $\log$ (asset) & $\begin{array}{c}0.014 \\
(0.014)\end{array}$ & $\begin{array}{l}0.027^{*} \\
(0.016)\end{array}$ & $\begin{array}{c}0.016 \\
(0.016)\end{array}$ & $\begin{array}{l}0.031^{*} \\
(0.016)\end{array}$ & $\begin{array}{c}0.021 \\
(0.017)\end{array}$ \\
\hline firm_age & $\begin{array}{c}-0.006 \\
(-0.470)\end{array}$ & $\begin{array}{l}-0.005 \\
(0.014)\end{array}$ & $\begin{array}{l}-0.008 \\
(0.014)\end{array}$ & $\begin{array}{l}-0.006 \\
(0.014)\end{array}$ & $\begin{array}{l}-0.008 \\
(0.013)\end{array}$ \\
\hline gindex & $\begin{array}{c}0.037 * * * * \\
(0.010)\end{array}$ & $\begin{array}{c}0.046 * * * \\
(0.011)\end{array}$ & $\begin{array}{c}0.047 * * * \\
(0.011)\end{array}$ & $\begin{array}{c}0.042 * * * \\
(0.011)\end{array}$ & $\begin{array}{c}0.043 * * * \\
(0.011)\end{array}$ \\
\hline
\end{tabular}

\footnotetext{
${ }^{5}$ Regressions are estimated with firm fixed effect, year fixed effect, and industry fixed effect (2 digit SIC code). Standard errors are in parenthesis.
} 
End of Table 2

\begin{tabular}{|c|c|c|c|c|c|}
\hline & Model 1 & Model 2 & Model 3 & Model 4 & Model 5 \\
\hline percentage of ownership & $\begin{array}{c}-0.068^{* * * *} \\
(0.010)\end{array}$ & $\begin{array}{c}-0.059 * * * \\
(0.012)\end{array}$ & $\begin{array}{c}-0.065^{* * *} \\
(0.012)\end{array}$ & $\begin{array}{c}-0.058 * * * \\
(0.011)\end{array}$ & $\begin{array}{c}-0.063 * * * \\
(0.012)\end{array}$ \\
\hline tenure & & $\begin{array}{c}0.001 \\
(0.011)\end{array}$ & $\begin{array}{c}0.009 \\
(0.011)\end{array}$ & $\begin{array}{c}0.002 \\
(0.011)\end{array}$ & $\begin{array}{c}0.008 \\
(0.011)\end{array}$ \\
\hline total compensation & & $\begin{array}{l}-0.005 \\
(0.011)\end{array}$ & $\begin{array}{l}-0.006 \\
(0.011)\end{array}$ & $\begin{array}{c}-0.056^{* * *} \\
(0.015)\end{array}$ & $\begin{array}{c}-0.043 * * * \\
(0.016)\end{array}$ \\
\hline financial slack & & $\begin{array}{c}0.042 * * * \\
(0.011)\end{array}$ & $\begin{array}{c}0.054 * * * \\
(0.011)\end{array}$ & $\begin{array}{c}0.051 * * * \\
(0.011)\end{array}$ & $\begin{array}{c}0.062 * * * \\
(0.012)\end{array}$ \\
\hline human slack & & $\begin{array}{c}0.011 \\
(0.009)\end{array}$ & $\begin{array}{c}-0.046 * * * \\
(0.013)\end{array}$ & $\begin{array}{c}-0.054 * * * \\
(0.014)\end{array}$ & $\begin{array}{c}-0.084 * * * \\
(0.015)\end{array}$ \\
\hline financial slack*tenure & & & $\begin{array}{c}0.055^{* * *} \\
(0.015)\end{array}$ & & $\begin{array}{c}0.050 * * * \\
(0.015)\end{array}$ \\
\hline human slack*tenure & & & $\begin{array}{c}0.073 * * * \\
(0.012)\end{array}$ & & $\begin{array}{c}0.057 * * * \\
(0.012)\end{array}$ \\
\hline $\begin{array}{l}\text { financial slack*total } \\
\text { compensation }\end{array}$ & & & & $\begin{array}{c}0.047 * * * \\
(0.013)\end{array}$ & $\begin{array}{c}0.042 * * * \\
(0.013)\end{array}$ \\
\hline $\begin{array}{l}\text { human slack*total } \\
\text { compensation }\end{array}$ & & & & $\begin{array}{c}0.197 * * * \\
(0.031)\end{array}$ & $\begin{array}{c}0.154 * * * \\
(0.032)\end{array}$ \\
\hline firm fixed effect & yes & yes & yes & yes & yes \\
\hline year effect & yes & yes & yes & yes & yes \\
\hline industry fixed effect & yes & yes & yes & yes & yes \\
\hline $\mathrm{N}$ & 7729 & 5522 & 5522 & 5522 & 5522 \\
\hline R2 & 0.303 & 0.307 & 0.313 & 0.312 & 0.316 \\
\hline Adjusted R2 & 0.300 & 0.303 & 0.308 & 0.308 & 0.311 \\
\hline Change in R2 & & 0.004 & 0.006 & 0.006 & 0.009 \\
\hline F stat & & 2.038 & 2.895 & 2.795 & 4.146 \\
\hline $\mathrm{p}$ value & & 0.012 & 0.000 & 0.000 & 0.000 \\
\hline
\end{tabular}

Notes: ${ }^{*},{ }^{* *},{ }^{* * *}$ indicate significance at the $10 \%, 5 \%$, and $1 \%$ levels, respectively.

In Table 2, we report the results of the regression analysis. The number of observations drops from 7729 to 5522 due to missing observations (mainly because of the variable emp from Execucomp which was not populated for all firm years). The coefficient on financial slack is positive and significant, in support of hypothesis 1a (column 2). Firms with greater financial slack are able to allocate more resources to risky projects through increased R\&D investment. However, even though the coefficient on human slack is positive, it is insignificant and does not support hypothesis $1 \mathrm{~b}$. In column 3 , we report 
the results for Model 3 which includes the interactions of tenure with financial slack and tenure with human slack. The coefficient of tenure with financial slack is positive (0.055) and significant, lending support to hypothesis 2a. Managers with higher levels of tenure allocate more financial resources to $\mathrm{R} \& \mathrm{D}$ investments. The coefficient of tenure with human slack is positive (0.073) and significant, in support of hypothesis $2 \mathrm{~b}$. More tenured managers put greater human resources into risky investments such as R\&D.

In column 4, we document the regression estimates for Model 4. Model 4 includes the interactions of total compensation with financial slack and human slack. The coefficient of total compensation with financial slack is positive (0.047) and significant, supporting hypothesis 3a. Managers with greater total compensation allocate more financial resources to innovation. Further, the coefficient of the interaction of total compensation with human slack is also positive, supporting hypothesis 3b. Managers with higher levels of compensation direct more human resources towards R\&D.

In column 5, we report the results of Model 5, which includes the interactions of tenure with financial slack and human slack, and the interactions of total compensation with financial slack and human slack. All four coefficients of the four interaction terms are positive and significant, in support of hypotheses $2 \mathrm{a}, 2 \mathrm{~b}, 3 \mathrm{a}$, and $3 \mathrm{~b}$. The coefficient of financial slack is also positive and significant, supporting hypothesis 1a. Overall, the results reported in columns 2, 3, 4 and 5 support our hypothesis $1 \mathrm{a}, 2 \mathrm{a}, 2 \mathrm{~b}, 3 \mathrm{a}$ and $3 \mathrm{~b}$.

\section{Discussions}

Our results confirm our original supposition that both financial and human slack impact firm R\&D spending and that both CEO tenure and CEO compensation are important in securing the funding and people needed to initiate and complete R\&D projects. These outcomes clearly show that CEOs with longer tenure are more willing to risk R\&D initiatives and that proper and thoughtful compensation packages could strongly motivate CEOs to pay more attention to the innovation process.

This work contributes to the literature in several ways. First, we analyze the slackinnovation relationship. We specifically focus on the relationship between financial and human slack and their impact on R\&D investment which surprisingly has received little or no attention especially given that such R\&D related allocation decisions are one of most fundamental decisions made by top managers (Barker, Mueller 2002). Thus, we extend the work of Nohria and Gulati (1996) by using objective measures for both independent and dependent variables, and also answering calls to use firm-level panel data to gain deeper insights into the slack-innovation relationship, increasing the relevance and importance of the work. The sample extends from 1993 to 2011 and contains 7729 firmyears, making the results strong, robust, and generalizable. Second, this study focuses on the combination of CEO tenure and compensation and their impact on the slackinnovation relationship, therefore making it the first study to our knowledge to report how CEO tenure and CEO compensation moderates the slack-innovation relationship. Third, we draw on a number of theories such as RBV and upper echelons to enhance our understanding of these relationships. Fourth, this study moves away from the traditional 
emphasis only on financial slack by considering a different type of organizational slack (i.e., human slack) that has not been studied as often in the literature, thereby enhancing our understanding of its influence.

Key implications of this work directly impact managers, investors, and board members. For example, we hope that our results encourage these leaders to think carefully about the various characteristics of the CEO (e.g., tenure) and about the details of the compensation package they offer. Without a doubt, slack resources matter. But more insights and studies are needed to fully understand how to best manage slack resources without wasting them. For instance, although beyond the scope of this paper, the law of diminishing returns might kick in at a certain point thus reducing the impact of each additional resource on firm innovation levels ${ }^{6}$. Further, testing our results with a sample of small firms, or in different international settings, might prove useful as well. Smaller firms might find it difficult to maintain the levels of slack needed for considerable R\&D investments and resource allocation decisions might become even more complex. Looking further into international firms, especially those in developing countries might be necessary given the essential role of innovation in attaining and sustaining competitive advantage in developing countries where industrial growth has become integral to economic development (Ooi et al. 2012). Firms in developing countries in hypercompetitive global environments that seek long-term success are increasingly focusing on innovation and shifting away from cost reduction efforts. Therefore, a better understanding of how managers make resource allocation decisions in such environments might differ from research that focused on samples from western countries (e.g., Voss et al. 2008).

\section{Conclusions}

This study contributes to the understanding of the complex links between organizational slack, CEO tenure, CEO compensation, and R\&D investments. Our findings point to the importance of both financial and human slack for firms' ability to innovate. Our results also show that our grasp of the slack-innovation relationship is not complete without studying CEO tenure and compensation.

\section{References}

Allgood, S.; Farrell, K. 2000. The effect of CEO tenure on the relation between firm performance and turnover, Journal of Financial Research 23(3): 373-390.

Arthur, W. 1989. Competing technologies, increasing returns, and lock-in by historical events, Economic Journal 99(394): 116-131. http://dx.doi.org/10.2307/2234208

Audretsch, D. 1995. Firm profitability, growth and innovation, Review of Industrial Organization 10(5): 579-588. http://dx.doi.org/10.1007/BF01026883

Balkin, D. B.; Markman, G. D.; Gomez-Mejia, L. 2000. Is CEO pay in high-technology firms related to innovation?, Academy of Management Journal 43(6): 1118-1129.

http://dx.doi.org/10.2307/1556340

\footnotetext{
${ }^{6}$ We would like to thank an anonymous reviewer for bringing this point to our attention.
} 
Bamford, C. E.; Dean, T. J.; McDougall, P. P. 2000. An examination of the impact of initial founding conditions and decisions upon the performance of new bank start-ups, Journal of Business Venturing 15(3): 253-277. http://dx.doi.org/10.1016/S0883-9026(98)00011-1

Barker, V. L., III; Mueller, G. C. 2002. CEO characteristics and firm R\&D spending, Management Science 48: 782-801. http://dx.doi.org/10.1287/mnsc.48.6.782.187

Barney, J. 1991. Firm resources and sustained competitive advantage, Journal of Management 17(1): 99-120. http://dx.doi.org/10.1177/014920639101700108

Baysinger, B. D.; Kosnik, R. D.; Turk, T. A. 1991. Effects of board and ownership structure on corporate strategy, Academy of Management Journal 34(1): 205-214.

http://dx.doi.org/10.2307/256308

Berger, P.; Ofek, E.;Yermack, D. 1997. Managerial entrenchment and capital structure decisions, Journal of Finance 52: 1411-1438. http://dx.doi.org/10.1111/j.1540-6261.1997.tb01115.x

Bourgeois, L. I.; Singh, J. V. 1983. Organizational slack and political behavior among top management teams, in Academy of Management Proceedings: 43-49.

Bradley, S. W.; Wiklund, J.; Shepherd, D. A. 2011. Swinging a double-edged sword: the effect of slack on entrepreneurial management and growth, Journal of Business Venturing 26: 537-554. http://dx.doi.org/10.1016/j.jbusvent.2010.03.002

Chhaochharia, V.; Grinstein, Y. 2009. CEO compensation and board structure, Journal of Finance 64(1): 231-261. http://dx.doi.org/10.1111/j.1540-6261.2008.01433.x

Chi, M. T. H.; Glaser, R.; Farr, M. J. 1988. The nature of expertise. Hillsdale, N. J.: Erlbaum Associates.

Cleary, S. 1999. The relationship between firm investment and financial status, Journal of Finance 54: 673-691. http://dx.doi.org/10.1111/0022-1082.00121

Cohen, W.; Klepper, S. 1996. Firm size and the nature of innovation within industries: the case of process and product R\&D, The Review of Economics and Statistics 78(2): 232-243.

http://dx.doi.org/10.2307/2109925

Cooper, A. C.; Gimeno-Gascon, F. J.; Woo, C. Y. 1994. Initial human and financial capital as predictors of new venture performance, Journal of Business Venturing 9: 371-395.

http://dx.doi.org/10.1016/0883-9026(94)90013-2

Core, J.; Guay, W. 1999. The use of equity grants to manage to manage optimal equity incentive levels, Journal of Accounting and Economics 28: 151-184.

http://dx.doi.org/10.1016/S0165-4101(99)00019-1

Cremers, K. J.; Nair, V. 2005. Governance mechanisms and equity prices, Journal of Finance 60(6): 2859-2894. http://dx.doi.org/10.1111/j.1540-6261.2005.00819.x

Cyert, R. M.; March, J. G. 1963. A behal theory of the firm. Englewood Cliffs, NJ.: Prentice-Hall. David, P. 1985. Clio and the economics of QWERTY, The American Economic Review 75(2): 332-337.

DiMasi, J. A.; Hansen, R. W.; Grabowski, H. G. 2003. The price of innovation: new estimates of drug development costs, Journal of Health Economics 22(2): 151-185.

http://dx.doi.org/10.1016/S0167-6296(02)00126-1

Edder, R. W.; Ferris, G. R. 1989. The employment interview: theory, research and practice. Newbury Park, CA: Sage.

Finkelstein, S.; Hambrick, D. C. 1996. Strategic leadership: top executives and their effects on organizations. New York: West Publishing Company.

Francis, J.; Smith, A. 1995. Agency cost and innovation: some empirical evidence, Journal of Accounting and Economics 19(2-3): 383-409.

http://dx.doi.org/10.1016/0165-4101(94)00389-M 
Frank, R. 2007. How the rich invest, Wall Street Journal [online]. Available from Internet: http:// blogs.wsj.com/wealth/2007/06/12/how-the-rich-invest/.

Galbraith, J. R. 1973. Designing complex organizations. Reading, MA: Addison-Wesley.

Gompers, P.; Ishii, J.; Metrick, A. 2003. Corporate governance and equity prices, Quarterly Journal of Economics 118: 107-155. http://dx.doi.org/10.1162/00335530360535162

Greve, H. R. 2003. A behavioral theory of R\&D expenditures and innovations: evidence from shipbuilding, Academy of Management Journal 46(6): 685-702. http://dx.doi.org/10.2307/30040661

Guay, W. 1999. The sensitivity of CEO wealth to equity risk: an analysis of the magnitude and determinants, Journal of Financial Economics 53: 43-71.

http://dx.doi.org/10.1016/S0304-405X(99)00016-1

Hambrick, D. C.; Finkelstein, S. 1987. Managerial discretion - a bridge between polar views of organizational outcomes, Research in Organizational Behavior 9: 369-406.

Hambrick, D.; Mason, P. 1984. Upper echelons: the organization as a reflection of its top managers, Academy of Management Review 9(2): 193-206.

Hansen, J. 1992. Innovation, firm size and firm age, Small Business Economics 4: 37-44.

Hermalin, B.; Weisbach, M. 1998. Endogenously chosen boards of directors and their monitoring of the CEO, American Economic Review 88(1): 96-118.

Hill, C.; Phan, P. 1991. CEO tenure as a determinant of CEO pay, The Academy of Management Journal 34(3): 707-717. http://dx.doi.org/10.2307/256413

Kim, H.; Kim, H; Lee, P. M. 2008. Ownership structure and the relationship between financial slack and R\&D investments, Organization Science 19(3): 404-418.

http://dx.doi.org/10.1287/orsc. 1080.0360

Knorr-Cetina, K. 1999. Epistemic cultures. Cambridge, MA: MIT Press.

Kraatz, M. S.; Zajac, E. J. 2001. How organizational resources affect strategic change and performance in turbulent environments: theory and evidence, Organization Science 12(5): 632-657. http://dx.doi.org/10.1287/orsc.12.5.632.10088

Latham, S. F.; Braun, M. R. 2008. The performance implications of financial slack during economic recession and recovery: observations from the software industry (2001-2003), Journal of Managerial Issues 20(1): 30-50.

Leonard-Barton, D. 1995. Wellsprings of knowledge. Boston: Harvard Business School Press.

Levinthal, D.; March, J. G. 1981. A model of adaptive organizational search, Journal of Economic Behavior and Organization 2(4): 307-333. http://dx.doi.org/10.1016/0167-2681(81)90012-3

Mazzucato, M.; Tancioni, M. 2012. R\&D, patents and stock returns volatility, Journal of Evolutionary Economics 22(4): 811-832. http://dx.doi.org/10.1007/s00191-012-0289-x

Mishina, Y.; Pollock, T. G.; Porac, J. F. 2004. Are more resources always better for growth? Resource stickiness in market and product expansion, Strategic Management Journal 25(12): 1179-1197. http://dx.doi.org/10.1002/smj.424

Mosakowski, E. 2002. Overcoming resource disadvantages in entrepreneurial firms: when less is more, in M. Hitt, D. Ireland, D. Sexton, M. Camp (Eds.). Strategic entrepreneurship: creating an integrated mindset. Oxford: Blackwell, 106-126.

Mousa, F. T.; Reed, R. 2013. The impact of slack resources on high-tech IPOs, Entrepreneurship Theory and Practice 37(5): forth coming.

Nohria, N.; Gulati, R. 1996. Is slack good or bad for innovation? Academy of Management Journal 39(5): 1245-1264. http://dx.doi.org/10.2307/256998

O'Brien, J. P. 2003. The capital structure implications of pursuing a strategy of innovation, Strategic Management Journal 24: 415-431. http://dx.doi.org/10.1002/smj.308 
Ooi, K.; Lin, B.; Teh, P.; Chong, A. 2012. Does TQM support innovation performance in Malaysia's manufacturing industry?, Journal of Business Economics and Management 13(2): 366-393. http://dx.doi.org/10.3846/16111699.2011.620155

Penrose, E. 1959. The theory of the growth of the firm. New York: Wiley.

Saviotti, P. P.; Mani, G. S. 1998. Technological evolution, self-organization, and knowledge, Journal of High Technology Management Research 9: 255-271.

Schumpeter, J. A. 1934. The theory of economic development. Cambridge, MA: Harvard University Press.

Singh, J. V. 1986. Performance, slack, and risk taking in organizational decision making, The Academy of Management Journal 29(3): 562-585. http://dx.doi.org/10.2307/256224

Singh, M.; Faircloth, S. 2005. The impact of corporate debt on long term investment and firm performance, Applied Economics 37(8): 875-883. http://dx.doi.org/10.1080/00036840500076762

Szewczyk, S. H.; Tsetsekos, G. P.; Zantout, Z. 1996. The valuation of corporate R\&D expenditures: evidence from investment opportunities and free cash flow, Financial Management 25(1): 105-10. http://dx.doi.org/10.2307/3665906

Szulanski, G. 2003. Sticky knowledge - barriers to knowing in the firm. UK, London: Sage Publications.

Van de Ven, A. H. 1986. Central problems in the management of innovation, Management Science 32: 590-607. http://dx.doi.org/10.1287/mnsc.32.5.590

Voss, G. B.; Sirdeshmukh, D.; Voss, Z. G. 2008. The effects of slack resources and environmental threat on product exploration and exploitation, Academy of Management Journal 51(1): 147-164. http://dx.doi.org/10.5465/AMJ.2008.30767373

Williamson, O. E. 1963. A model of rational managerial behavior, in R. M. Cyert, G. March (Eds.). A behavioral theory of the firm. Englewood Cliffs, NJ: Prentice-Hall.

Wiseman, R. M.; Gomez-Mejia, L. R. 1998. A behavioral agency model of managerial risk taking, The Academy of Management Journal 23(1): 133-153.

Wu, S.; Levitas, E.; Priem, R. L. 2005. CEO tenure and company invention under differing levels of technological dynamism, The Academy of Management Journal 48(5): 859-873.

http://dx.doi.org/10.5465/AMJ.2005.18803927

Fariss-Terry MOUSA is currently an Assistant Professor of Management with James Madison University Zane Showker College of Business. Dr. Mousa received his PhD in Strategic Management in 2009 from Washington State University College of Business. He researches, publishes, and lectures in the fields of strategic management, entrepreneurship, and innovation. He has published in a wide range of leading journals such as the Strategic Management Journal, Entrepreneurship Theory and Practice, Journal of Business Economics and Management, Management Decision, and International Small Business Journal.

Jaideep CHOWDHURRY is an Assistant Professor in Finance at James Madison University. Dr. Chowdhury received a PhD in Finance in 2011 from Virginia Tech. His research interest consists of wide range of topics including executive compensation, mutual funds, CEO characteristics and organizational slack. 